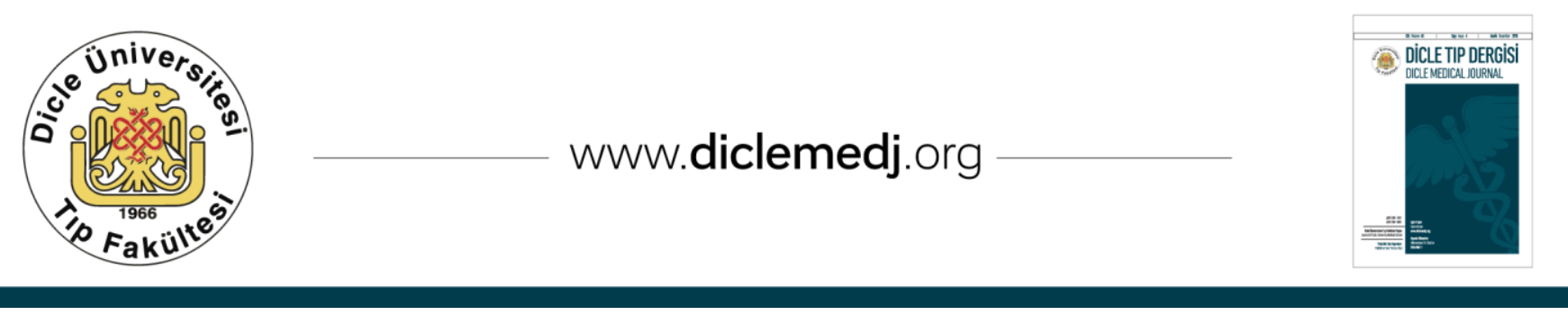

\title{
Yeni Bir Hemostatik Ajan Olan Mecsina Hemostopper® 'ın Farklı Testlerle Sitotoksisitesinin Değerlendirilip, Kalvarial Osteoblast Proliferasyonuna Etkisinin Araştırılması
}

\author{
Mustafa Çiçek¹, Mehmet Kemal Tumer ${ }^{2,3}$ \\ 1 Sütçü İmam Üniversitesi, Tıp Fakültesi, Anatomi Anabilim Dall, Kahramanmaraș, Türkiye ORCID: 0000-0001-8925-0230 \\ 2 Gaziosmanpaşa Üniversitesi, Diş Hekimliği Fakültesi, Ağız, Diş Ve Çene Cerrahisi Anabilim Dalı, Tokat, Türkiye ORCID: 0000-0002-6250-0954 \\ 3 Gaziosmanpaşa Üniversitesi, Tıp Fakültesi, Tıbbi Biyoloji Anabilim Dall, Tokat, Türkiye
}

Geliş: 31.01.2018, Revizyon: 29.06.2018, Kabul Tarihi: 23.07.2018

$\ddot{\mathbf{O z}}$

Amaç: Tıp ve diş hekimliğinin birçok dalında kanama komplikasyonu, gerçekleştirilen tedaviler sonrası veya sırasında, yapılan işlemin büyüklüğünden bağımsız olarak gelişebilir. İyi ve etkin bir cerrahi operasyon için, operasyon sırasında ve sonrasında hemostazın sağlanması en önemli cerrahi gereksinimlerin başında gelmektedir Sağlık alanında aktif olarak kullanılan antihemorajik ajanlar farklı etki mekanizmaları kullanarak kanamayı engelleyebilir. Bu çalışmada yeni nesil bir anti-hemorajik ajan olan "Mecsina Hemostopper@” In etki mekanizmasının, XTT (2,3-Bis(2-metoksi4-nitro-5-sulfofenil)-2H-tetrazolyum) sitotoksisite analiz metodu ile fibroblast hücre proliferasyonu üzerine etkileri araştırılmıştır.

Yöntemler: Çalışma için insan 3T3-E1 osteoblast (non transformed human preosteoblastic cellline) ölümsüz hücre hatları ticari olarak satın alındı. Her flaska her bir farklı doz grubu için 5000 hücre olacak şekilde 9 gruba (mecsina 1/1, mecsina 1/2, mecsina $1 / 10$, mecsina $1 / 50$, mecsina $1 / 100$, mecsina $1 / 200$, mecsina $1 / 500$, distile su uygulanan negative ve hiçbir sey uygulanmayan kontrol ) hücreler dağıtıldı. 24 saat inkübasyondan sonra her bir grup için XTT analiz yöntemi ile sitotoksisite değerleri ölçülmüştür.

Bulgular: Mecsina Hemostopper kanama durdurucu ajanın osteoblast hücrelerinde farklı dozlarda ki ilaç uygulama grupları arasında anlamlı fark görüldü ( $\mathrm{p}<0,001)$. En fazla ölüm oranı $\% 100$ ve $\% 50$ 'lik ilaç uygulamalarında görülmüşken en fazla canlılık oranı \%1' lik grupta görülmüștür. \%10' luk konsantrasyonun ; \%2, \%1, \%0,5, \%0,2' lik konsantrasyondaki gruplar arasında istatistiksel olarak anlamlı ölçüde fark bulunmuştur $(\mathrm{p}<0,001)$.

Sonuç: Bu çalışmada, yeni nesil kanama durdurucu olan mecsina hemostopper gingival fibroblast hücre hatlarında; farklı konsantrasyonlarda farklı derecede sitotoksik değerleri olduğu saptanmıştır.

Anahtar Kelimeler: Mecsina Hemostopper, osteoblast, XTT, hemostatik ajan, kanama durducu.

DOI: $10.5798 /$ dicletip. 457247

Yazışma Adresi / Correspondence: Mehmet Kemal Tumer, Gaziosmanpaşa Üniversitesi, Diş Hekimliği Fakültesi, Ağız, Diş ve Çene Cerrahisi Anabilim Dall, Tokat, Türkiye e-mail: dr_kemaltumer@yahoo.com 


\title{
Investigation of the Effect of a New Hemostatic Agent Field Messina Hemostopper® on Proliferation of Calvarial Osteoblasts and Evaluation of Cytotoxicity by Different Tests
}

\begin{abstract}
Objective: Hemorrhagic complications may develop in many branches of medicine and dentistry after or during the treatment independently of the extent of the procedure performed. The maintenance of homeostasis per- and postoperatively is one of the most important surgical requirements for a good and effective surgical operation. Antihemorrhagic agents actively used in the field of health may prevent hemorrhage by using different mechanisms of action. In this study, the effects of the mechanism of action of "Mecsina Hemostopper ${ }^{\circ}$ ", a new generation antihemorrhagic agent, on fibroblast cell proliferation was investigated by using XTT (2,3-Bis-(2-Methoxy-4-nitro-5sulfophenyl)-2H-tetrazolium) cytotoxicity assay.

Methods: The immortalized human 3T3-E1 osteoblast (non-transformed human preosteoblastic cell line) cell lines were commercially purchased for the study. The cells, 5000 cells per flask for each different dose group, were distributed into the 9 groups (mecsina $1 / 1$, mecsina $1 / 2$, mecsina $1 / 10$, mecsina $1 / 50$, mecsina $1 / 100$, mecsina $1 / 200$, mecsina $1 / 500$, distilled water-administered negative and control without any administration). After the incubation for 24 hours, the cytotoxicity values were measured by XTT analysis technique for each group.

Results: There was a significant difference in the effects of Mecsina Hemostopper antihemorrhagic agent on fibroblast cells between different dose groups ( $p<0.001)$. The highest rate of survival was seen in the $1 \%$ group while the highest rate of mortality was seen with $100 \%$ and $50 \%$ drug administrations. There was a significant difference between the $2 \%, 1 \%, 0.5 \%$ and $0.2 \%$ concentration groups of $10 \%$ concentration $(\mathrm{p}<0.001)$.
\end{abstract}

Result: It has been found in this study that the mecsina hemostopper, a new generation antihemorragic agent, produced different cytotoxic levels at different concentrations in the gingival fibroblast cell lines

Keywords: Mecsina Hemostopper, osteoblast, XTT, hemostatic agent, bleeding stopper

\section{GİRIS}

Oral bölge hastalıkları ve cerrahisi diş çekimi, sert ve yumuşak dokulardaki lezyonların eksizyonu, ağız ve yüz bölgesinde oluşan travmatik olgular sonucu meydana gelen kırıkların tedavisi ya da preprotetik ve ortognatik cerrahi işlemler gibi birçok alanı kapsamaktadır. Tüm cerrahi uygulamalar opere edilmiş bölgede değişik derecelerde kanamalara sebep olmaktadır. Cerrahi uygulamanın iyi olması için operasyon sırasında ve sonrasında etkili bir hemostazın sağlanması ihtiyacı hayati derecede önem arz etmektedir. $\mathrm{Bu}$ nedenle birçok kanama durdurucu ajan operasyonlar sirasinda ve sonrasında yaygın bir şekilde kullanılmaktadır ${ }^{1}$.

Sağlık alanında hali hazırda aktif olarak kullanılan anti-hemorajik ajanlar farklı etki mekanizmaları kullanarak kanamayı engelleyebilir. "Mecsina Hemostopper®",
Glycyrrhizaglabra özü, Alpiniaofficinarum, Thymusserpyllum, syzygiumaromaticum, Hypericumperforatum, vitisvinifera, Urticaangustifolia, Menthaarvensis gibi bitkisel özlü ajanlardan yapılmaktadır. "Mecsina Hemostopper®" ortamında bir protein ağ oluşturarak vital eritrosit agregasyonunu sağlar. Uygulandığı bölgede özellikle fibrinojene bağlanarak protein ağı oluşturduğu ve bu ağa eritrositler ruloformasyonu şeklinde sıralandığı, yapılan elektron mikroskop deneylerinde kanitlanmıştır. $\mathrm{Bu}$ sayede hemostaza etkisi gözlemlenebilmiștir².

Osteoblastlar, kemik yapımından başlıca sorumlu genç kemik hücre tipi olarak tanımlanırlar. Organik ekstraselüler matriksin komponentlerini sentezlerler ve matriksin mineralizasyonunu kontrol ederler. $\mathrm{Bu}$ hücreler, fonksiyonel olarak kemik oluşum ve remodelingi için gerekli olan proteinleri (başta tip I kollajen ve diğer non-kollajenöz) ve 
proteoglikanları salgılayan hücrelerdir ${ }^{3}$. Osteoblastlar özellikle kemik yüzeylerinde, yan yaᄀna, tek katlı epiteli andıracak şekilde bulunurlar ${ }^{4}$. Bu minvalde düşünüldüğü zaman, kullandığımız bütün hemostatik ajanlar operasyon sırasında açığa çıkan kemik yüzeylerine ve çevre dokulara temas etmekte ve canlı dokuya uygulanan bu tür maddelerin doku üzerine olan etkilerinin bilimsel olarak araştırılması gerekmektedir.

Bu çalışmanın amacı, T.C. Sağlık Bakanlığı İlaç ve Eczacılık Genel Müdürlüğü tarafından eksternal kanamaların kontrolünde kullanılmak üzere ara ürün olarak ruhsatlandırılmış “Mecsina Hemostopper®”'ın sitotoksisite testinin ve daha önce araştırılmamış olan osteoblast proliferasyonuna etkisinin hücre kültürü ortamında XTT sitotoksisite analiz yöntemi ile araştırılmasıdır.

\section{YÖNTEMLER}

\section{Hücre Kültürü}

Bu çalışmada; Fare Kalvarial Osteoblastik hücre hattı (Mouse calvarial osteoblastic cell line 3T3E1-ECCAR; (MC3T3-E1 Subclone 4 (ATCC® CRL-2593 ${ }^{\text {TM }}$ )) ATCC (American Type Culture Collection)'den ticari olarak satın alındı. \%10 fetal dana serumu (Caprıcon) içeren DMEM (Dulbecco's modified eagle's Medium) ve HAM'S F12 (Capricon) besiyerinde $\% 95$ nem ve $\% 5$ karbondioksitli ortamda $37^{\circ} \mathrm{C}^{\prime}$ de inkübe edilerek çoğaltıldı. $25 \mathrm{~cm} 2$ 'lik flasklarda çoğaltılan hücreler, hücre kültür kaplarını kapladıkları zaman \%0.05 tripsin/EDTA (Caprıcon) çözeltisi ile flask yüzeyinden kaldırıldı. Pasajlama sırasinda yeni pasajda 1:2 hücre olacak şekilde hücre aktarımı yapıldı. Kültür besiyeri pasajdan sonra her iki günde bir değiştirildi. Daha sonra DMSO (Dimetilsülfoksit) ile dondurma protokolü uygulanarak stok olacak şekilde saklandı. Sigma markalı Tripan Blue (Product Number: T6146, CAS Number: 72-57-1) (\%0.05) boyası ile boyandıktan sonra Celeromics (Micro
Counter 1100, Grenoble/France) marka hücre sayım cihazı ile canlı ölü hücre miktarı tespit edildi. Yeterli hücre sayısına ulaştıktan sonra, her flaska her bir ilaç için 5000 hücre olacak şekilde 3 gruba (ilaç, distile su uygulanan negative, hiçbir şey uygulanmayan kontrol ) hücreler dağıtıldı.

\section{Hücre Proliferasyon Deneyi}

Bu test için 96'lık plağa 10.000 hücre ekilmiştir. 24 saat inkübasyondan sonra 1:1, 1:2, 1:10, 1:50, 1:100, 1:200 ve 1:500 dozlarında ilaç uygulanarak hücrelerde uygun doz bulunmuştur.

\section{In vitro sitotoksisite deneyleri}

Mecsina Blood Stopper hücrelerin tedavisinde kullanıldı. Hücreler ve ortam plakalara kültürlendi. Deneyler sirasinda oluşturduğumuz grupları içeren 6 kuyulu kültür kaplarında 5-10 milyon hücre üremesini takip ettik. Hedef rakama ulaşıldığında (24-48 saat) çalışma başlatıldı. Hücreler 96 kuyulu hücre kültür kaplarına 5000/kuyu olacak şekilde aktarıldı. 48 saat inkübatörde hücrelerin yapışması beklendi. XTT solüsyonu ile aktivasyon solusyonu karıștırıldı. 25 mikrolitre ( $\mu \mathrm{l})$ aktivasyon solüsyonu ile 5 mililitre (ml) XTT ajanını karıştırıp XTT nin aktifleşmesi sağlandı. Aktif olan XTT 'den $50 \mu \mathrm{l}$ alınıp $100 \mu \mathrm{l}$ kültür medium içeren hücre ile kaplı kuyulara eklendi. Hücreler 24 saat inkübatörde bekletildi. 24. saatin sonunda MRC UT-6100, Auto Microplate Reader cihazında ELISA yöntemi ile 450 nanometre (nm) dalga boyunda Atlas Biyoteknoloji Laboratuarmda analiz edildi ve gruplar arasında doz farklılı̆̆ına bağlı olarak oluşacak sitotoksik etki araştırıldı.

Istatistiksel Analizler

GraphPad Prism Sürüm 6.01'i (GraphPad Software, Inc., La Jolla CA, ABD, www.graphpad.com) kullanarak verileri analiz etmek için tek kuyruklu T-testi kullanıldı. Ttesti, muamele edilmiş hücrelerin ve muamele edilmemiş hücrelerin optik yoğunluğunu (OD) 
değerlerini karşılaştırmak için kullanıldı. İstatistiksel önem $\mathrm{p}<0.05$ olarak bildirildi. Bütün değerler ortalama \pm standart sapma (SD) olarak rapor edildi ve bunlar Microsoft Excel Ver.3.2013 kullanılarak hesaplandı.

\section{BULGULAR}

Mecsinanın osteoblast hücre proliferasyonuna doza bağımlı etkisi analiz edildi (Grafik 1). Mecsinanin \%100, \%50, \%10, \%2, \% 1, \%0,05, $\% 0,02$ ' lik konsantrasyonlardaki hücre canlılık oranları 24 saat sonunda tespit edildi. Mecsinanın bu konsantrasyonlardaki inhibisyonu kontrol grubuyla klyaslandı (Grafik 2).

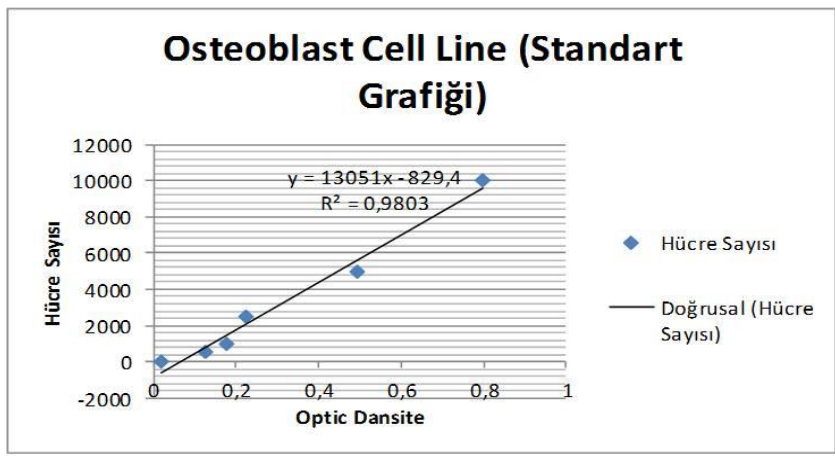

Figür 1: Osteoblast hücre hattı standart grafiği

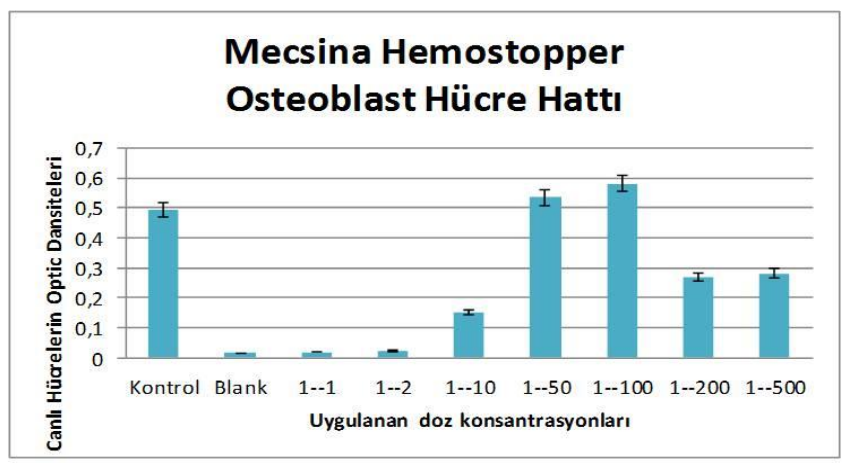

Figür 2: Kontrol osteoblast hücrelerinin ve farklı dozlarda mecsina hemostopper uygulaması yapılmıș osteoblast hücrelerinin optik dansite değerlerinin gösterimi

Mecsinanın osteoblast hücresine olan etkilerinin doz grupları arasında anlamlı fark görüldü $\quad(\mathrm{p}<0,001) . \quad \% 100$ ve $\% 50$ 'lik konsantrasyonda istatistiksel olarak en fazla ölüm görülmüștür. \%10' luk konsantrasyonun ; $\% 2, \% 1, \% 0,5, \% 0,2$ ' lik konsantrasyondaki gruplar arasinda istatistiksel olarak anlamlı ölçüde fark bulunmuştur $(\mathrm{p}<0,001)$. Hem \%2' lik grubumuz ile \%1' lik grubumuz arasinda hem de $\% 0,5$ ve $\% 0,2^{\prime}$ lik grubumuz arasinda istatistiksel olarak anlamlı fark bulunamamıştır ( $p>0,05)$. En yüksek canlılık düzeyi $\% 2$ ve $\% 1^{\prime}$ lik gruplarımızda gözlemlenmiștir. Hücrelerdeki canlılık oranlarına bakıldığ zaman $\% 2$ ve $\% 1$ ' lik grupların ayrı ayrı $\% 0,5$, $\% 0,2^{\prime}$ lik doz konsantrasyonundaki gruplarımıza göre istatistiksel olarak anlamlı farklılık bulunmuştur $(\mathrm{p}<0,001)$ (Grafik 3).

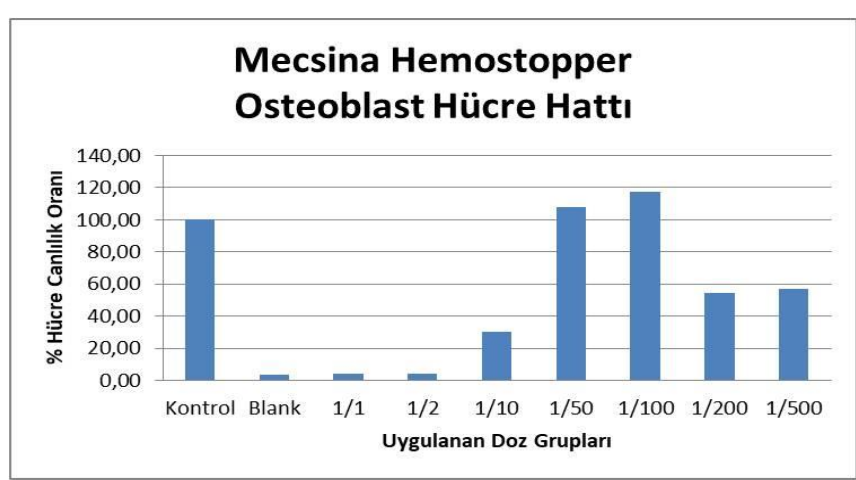

Figür 3: Kontrol osteoblast hücrelerinin ve farklı dozlarda mecsina hemostopper uygulaması yapılmıș osteoblast hücrelerinin hücre canlılık oranlarının \% değisșimleri

\section{TARTIȘMA}

Operasyon sırasında ve sonrasında kanamanın kontrolü cerrahinin temel prensiplerinden biri olmaktadır. Özellikle koagulopati hastalığı olan bireylerde bu durum daha da bir önem kazanmaktadır. Diş hekimliği cerrahisinde halen kullanılmakta olan farklı tipte kanama durdurucu birçok ajan bulunmaktadır. Diş hekimliği klinik uygulamalarında en çok kullanılan kanama durdurucu ajanlar selülöz kaynaklı olanlardır ${ }^{1}$. Yapılan bir çalışmada warfarin kullanımı olan ve INR değeri 1-4 arasındaki hastaların diş çekim boşluklarına rejenere okside selüloz kullanılmış ve hiçbir hastasında kanamayı kontrol etmek için ikinci 
bir kanama durdurucu kullanımına gerek duyulmamıştır5. Başka bir çalışmada ise warfarin kullanımı kesilmeden yapılan periodontal tedavi gerçekleştirilmiş hastalara kanama durdurucu olarak uygulanan okside selülozun kanama kontrolünde etkin olduğu gösterilmiştir6. Günümüzde kanamanın kontrolü için yeni bir çok hemostatik ajan üretilmekte ve kullanılmaktadır. Çalışmamızda kullandığımız mecsina hemostopper da yakın zamanda literatüre girmiş doğal kaynakları bünyesinde bulunduran bir kanama durdurucu materyaldir. Yeni bir madde olması nedeniyle mecsina hemostopper üzerinde yapılmış nitelikli bir çalışma bulunmamaktadır. Bu kapsamda çalışmamız literatürde bir ilk olma özelliği taşımaktadır.

İnsan vücudunda bulunan kök hücreler farklı hücrelere dönüșebilmektedir ${ }^{7}$. Embriyo kaynaklı kök hücreler gelişimsel ya da doğum sonrası (organ veya doku spesifik ve erişkin kök hücreler) kök hücre olarak ikiye ayrılmaktadır ${ }^{8}$. Erişkin kök hücreler, kemik iliği, kas, deri, sinir dokus, bağırsak, diş pulpası, karaciğer, periodontal ligament, alveolara kemik ve ekstrakte edilmiş kalıcı dişlerden elde edilmektedir9. Ayrica organ veya dokuya spesifik kök hücre özellikleri kök hücrelerin davranışlarını etkilemektedir ${ }^{10}$. Oral ve maksillofasiyal bölgedeki pek çok tıbbi uygulamada, kök hücre araştırması hızla artmaktadır ${ }^{11}$. Bu nedenle çalışmamızda kaliteli ve deney sonuçlarımızın güvenilir olması için ticari osteoblast hücre hattı kullanılması tercih edilmiștir.

Mecsina Hemostopper®", Glycyrrhizaglabra özü, Alpiniaofficinarum, Thymusserpyllum, syzygiumaromaticum, Hypericumperforatum, vitisvinifera, Urticaangustifolia, Menthaarvensis gibi bitkisel özlü ajanlardan yapılmaktadır. Bu bitkilerin tümü endotel, kan hücreleri, hücresel proliferasyon, anjiyogenez, mediatörler ve vasküler dinamikler üzerinde etki oluşturmaktadır ${ }^{12}$. Mecsina Hemostopper'ın etki mekanizması, kapsüllenmiş protein ağı oluşturma yoluyla eritrosit agregasyonu odak noktalarının oluşumunu sağlamaktır ${ }^{2} . \mathrm{Bu}$ etkisini fibroblastlar üzerinde göstermekte iken osteoblast hücrelerinde nasıl bir etki mekanizması olduğu henüz bilinmemektedir. Çalışmamızda Mecsina Hemostopper'ın osteoblast hücre hattı üzerine nasıl bir toksik etki gösterdiği analiz edilmeye çalışılmıştır.

Kanama kontrolünü sağlamak ve postoperatif dönemde kanama insidansını en aza indirmek için eskiden beri çeşitli yöntemler denenmiştir ${ }^{13}$. Kanama durdurucu ajan olarak kullanılan maddeler kemik yüzeyleri ile temas etmektedirler. Bu durumun neden olduğu doku reaksiyonları, kullanılan malzemelerin güvenilirliği açısından önemlidir. Uygulama sonunda dokularda herhangi bir nekroz alanı ve yabancı cisim reaksiyonlarının olmaması maddenin güvenilirliğini göstermektedir ${ }^{14}$. Bu açıdan bakıldığı zaman çalışmamızda mecsina hemostopper isimli kanama durducu ajanın sitotoksik etkisini göstermek için XTT analizi yapılmıştır. Araştırma bulgularımıza göre düşük doz konsantrasyonlarda yapılan uygulamada hücre canlılık oranları en yüksek seviyede tespit edilmiştir. Ayrıca yüksek doz ilaç uygulamalarında ise hücre canlılık oranlarında ciddi bir azalma görülmüştür.

Sonuç olarak, mecsina hemostopper bir bitki özütü olup hemostatik bir ajan olarak kullanılmıștır. Kesin etki mekanizması bilinmemekteyken ilaç içeriğini oluşturan bitkilerin çeşitli şekillede hemostatik sistem üzerinde bir etkisinin olduğunu bilmekteyiz. Çalışmamızın sonuçları bize mecsinanın sitotoksik ve proliferatif etkilerinin ilacin post ya da pre-operatif olarak uygulanmasinda klinik olarak bir rahatsızlık doğurmadığını göstermiştir. Ancak çalışmamız literatürdeki ilk çalışma olması nedeniyle ilacın etki mekanizması hakkında daha kapsamlı çalışmalar yapılması gerekmektedir. 
Çıkar Çatışması Beyanı: Yazarlar çıkar çatışması olmadığını bildirmişlerdir.

Finansal Destek: Bu çalışma, Gaziosmanpaşa Üniversitesi Bilimsel Araştırma Projeleri Koordinasyon Birimince Desteklenmiştir. Proje Numarası: 2013/103

Declaration of Conflicting Interests: The authors declare that they have no conflict of interest.

Financial Disclosure: This study was supported by Scientific Research Projects Coordination Unit of Gaziosmanpasa University. Project number: 2013/103.

\section{KAYNAKLAR}

1. Simsek HO, Tüzüm MS, Baykul T, Gürer IE, Başsorgun CI. Experimental investigation of the effects of a blood stopper agent (ankaferd blood stopper) on bone surfaces. Turkish Journal of Hematology. 2013; 30: 177-83.

2. Ozyurt A. Düşük enerji seviyeli lazer terapisi ve mecsina adlı hemostatik ajan kullanılarak sert doku iyileşmesinin histolojik ve morfolojik değerlendirilmesi. Doktora Tezi. Gazi Üniversitesi Sağlık Bilimleri Enstitüsü, Ankara. 2014.

3. Gartner LP, Hiatt JL. Color Textbook of Histology, 3rd edn. Philadelphia: W. B. Saunders, 2001: 577.

4. Lindhe J, Karring T, Lang NP. Clinical Periodontology and Implant dentistry, 4th edn. Copenhagen: Blackwell Munksgaard, 2003: 1072.

5. Pekkan G, Tuna SH, Oghan F. Extraoral prostheses using extraoral implants. Int J Oral Max Surg. 2006; 40: 378-83
6. Morimoto Y, Niwa H, Minematsu K. Hemostatic management for periodontal treatments in patients on oral antithrombotic therapy: a retrospective study. Oral Surg Oral Med Oral Pathol Oral Radiol Endod. 2009; 108: 889-96.

7. Otto WR, Rao J. Tomorrows skeleton staff: Mesenchymal stem cells and the repair of bone and cartilage. Cell Prolif. 2004; 37: 97-110.

8. Grove JE, Bruscia E, Krause DS. Plasticity of bone marrow - derived stem cells. Stem Cells. 2004; 22 : 487-500.

9. Miura M, Gronthos S, Zhao M, et al. SHED: stem cells from human exfoliated deciduous teeth. Proc Natl Acad Sci USA. 2003; 100: 5807-12.

10. Akintoye So, Lam T, Shi S, Brahim J, Collins MT, Robey PG. Skeletal site-specific characterization of orofacial and iliac crest human bone marrow stromal cells in same individuals. Bone. 2006; 38: 758-68.

11. Shi S, Bartold PM, Miura M, Seo BM, Robey PG, Gronthos S. The efficacy of mesenchymal stem cells to regenerate and repair dental structures. Orthod Craniofac Res. 2005; 8: 191-9.

12. Goker H, Haznedaroglu IC, Ercetin S, et al. Haemostatic actions of the folkloric medicinal plant extract, Ankaferd Blood Stopper. J Int Med Res. 2008; 36: $163-70$

13. Yıldırım M, Günyel E, Topçu İ. The Hemostatic Effect of Bizmut Subgallat in Tonsillectomy. Dicle Med J. 2007; 34: $1-6$

14. Bilgili H, Captug O, Kosar A, et al. Oral systemic administration of Ankaferd Blood Stopper has no shortterm toxicity in an in vivo rabbit experimental model. Clin Appl Thromb Hemost. 2010; 16: 533-6. 